\title{
Organisational Culture Attributes Influencing the Adoption of Agile Practices: A Systematic Literature Review
}

\author{
Elizabeth Sylvester Mkoba1 ${ }^{*}$, Carl Marnewick²
}

\begin{abstract}
${ }^{1}$ School of Computational \& Communication Science and Engineering, The Nelson Mandela African Institution of Science and Technology, Tanzania ${ }^{2}$ Department of Applied Information Systems, University of Johannesburg, South Africa

*Corresponding Author: elizabeth.mkoba@nm-aist.ac.tz
\end{abstract}

Citation: Mkoba, E. S., and Marnewick, C. (2022). Organisational Culture Attributes Influencing the Adoption of Agile Practices: A Systematic Literature Review. Journal of Information Systems Engineering and Management, 7(1), 11690. https://doi.org/10.55267/iadt.07.11690

\begin{abstract}
ARTICLE INFO
Received: 16 Jun. 2021

Accepted: 07 Dec. 2021

ABSTRACT

Organisations have been adopting agile practices to deliver information system projects faster and create business value. Despite its advantages, many organisations battle to successfully adopt agile practices. While there are several challenges for agile adoption, organisational culture has been amongst the challenges on adopting agile practices. The objective of this study was to determine the organisational culture attributes which influence the adoption of agile practices within the organisation. The systematic literature review aimed to explore the organisational culture attributes which influence the adoption of agile practices. The review focused on papers published on organisational culture influencing the adoption of agile practices between January 2015 to December 2020. The search strategy retrieved 204 papers of which nine papers were selected for a detailed analysis. The study revealed five factors of organisational culture that influence the adoption of agile practices in the organization as: management control, team collaboration, market, values and creativity. These factors have a number of organisational culture attributes that influence the adoption of agile practices. This study contributes to the body of knowledge by providing organisational culture attributes which influence the adoption of agile practices. The results of the systematic literature review presented in this study will benefit researchers and practitioners of project management.
\end{abstract}

Keywords: Organisation culture, Agile practices, Agile adoption, Systematic literature review, Information Systems

\section{INTRODUCTION}

Organisations have purpose, structure and processes to accomplish specific goals. These goals can be achieved through the organisational culture that comprises of behavior, values, norms and beliefs shared by all employees of an organisation (Schein 1988). The organisational culture has an impact on customer satisfaction, productivity, communication, teamwork and creating strategic business value to sustain organisation's competitive advantage in the market (Genç 2013). According to Pinto (2010) organisational culture also has impact on project success rate such as it affects team performance and commitment towards project goals as well as allocation of resources to projects. However, organisational culture has been amongst the challenges on adopting agile practices (Anwar et al. 2016; Ghimire 2020; Raharjo \& Purwandari 2020; VersionOne 2020). Other challenges are organisational resistance to change, inadequate management support and sponsorship (Ghimire et al. 2020; Raharjo \& Purwandari 2020). As organisations continue adopting agile practices to increase success rates of their projects
(PMI Pulse of the Profession 2017; Standish Group 2020), it is important for the organisation to recognize the organisational culture attributes that influence agile adoption.

In the literature there are studies published regarding the influence of organisational culture on agile adoption (Jivan et al. 2020; Othman et al. 2016; Soares \& Brodbeck 2018). However, there are no specific systematic reviews that determine organisational culture attributes which influence the adoption of agile practices. This research originality lies in the fact that up to now, no attempt has been made to specifically understand what organisational cultural factors influence the adoption of agile practices. The main purpose of this study is to determine the organisational culture attributes which influence the adoption of agile practices within the organisation. This systematic literature review aims to answer the following research question:

What are the organisational culture attributes that influence the adoption of agile practices?

The systematic literature review was chosen as a review method to identify literature on organisational culture atributes 
that influence the adoption of agile practices for inclusion, data cleaning, analysis and synthesis the findings, and the presentation of results. The methodology used in systematic literature review was adopted from Kitchenham et al. (2009) where the review protocol guided the study.

The article is organized as follows: Section 2 provides an overview of the research methodology. Section 3 presents the results of the systematic literature review. A discussion of the results is provided in Section 4. Finally, conclusion and recommendations for future research are presented in Section 5.

\section{RESEARCH METHODOLOGY}

The present study reviewed the existing literature that were published in peer-reviewed journals, conference papers, books, book chapters and academic journals from January 2015 to December 2020. This is a period where most organisations have been adopting agile project management to improve the success rates of information systems projects (PMI Pulse of Profession 2017; Standish Group 2020).

Data sources were from the following databases: The Association for Computing Machinery (ACM) Digital Library, IEEE Xplore, ScienceDirect, Scopus, Wiley Online Library, Springer Link, Emerald, Google Scholar and Sage Publishing. The choice of databases was based on the topic under review, the review question, methodological considerations and the bibliographic characteristics of scientific databases. These databases were used because they include multiple of highly ranked journals and conferences (Scopus 2020). These databases also have best literature coverage which contribute to comprehensiveness of the systematic literature review (Gusenbauer \& Haddaway 2019). The review protocol by Kitchenham et al. (2009) was adapted in this study as shown in Figure 1.

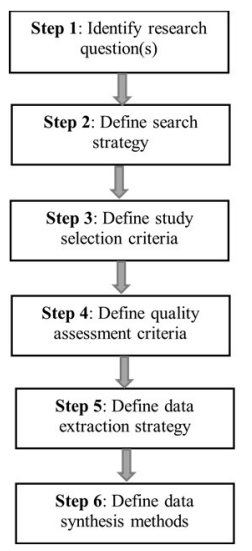

Figure 1. Systematic Literature Review protocol (Adapted from Kitchenham et al., 2009)
Step 1: Research question

The objective of this research is to determine organisational culture attributes that influence the adoption of agile practices. The following research question was defined to achieve the research objective:

What are the organisational culture attributes that influence the adoption of agile practices?

\section{Step 2: Search strategy}

The search strategy defined the search scope of studies by using the search string which was derived from the research question. The search string involved the following keywords with Boolean operators:

(("Organisational culture" OR "organisational culture" OR "Organisation culture" OR "organisation culture") AND ("cultural" OR "culture") AND ("adoption") AND ("Agile practices" OR "Agile practice" OR "Agile methods" OR "Agile method" OR "Agile methodologies" OR "Agile methodology" OR "Agile principle" OR "Agile principles" OR "Agile processes" OR "Agile process")).

This search string was used to search papers from electronic databases such as the Association for Computing Machinery (ACM) Digital Library, IEEE Xplore, ScienceDirect, Scopus, Wiley Online Library, Emerald Insight, SpringerLink, Google Scholar and Sage Publishing.

\section{Step 3: Study selection criteria}

A set of inclusion and exclusion criteria adopted from Kgoroeadira (2010) were used to reduce the number of studies by selecting the ones focusing on the purpose of the study. The exclusion criteria were:

- Abstract/ Title/Full text: Relevance to research question

- Date of publication: 2015 - 2020

- Language: Papers written in English

- Type of publications: Peer-reviewed journals, books chapters, conference and books

- Research method: Qualitative, quantitative, mixed method

- Geographic location: Worldwide

The screening of papers was performed through an online search of research articles in scientific journals which involved both search string and exclusion criteria. Articles were selected after their titles were related to search criteria and search string. After applying the search criteria 204 papers were selected from the databases. Table 1 shows the search results.

Table 1. Search results (2015-2020)

\begin{tabular}{|l|c|c|c|}
\hline \multicolumn{1}{|c|}{ Data source } & $\begin{array}{c}\text { Papers remaining after } \\
\text { applying exclusion criteria }\end{array}$ & $\begin{array}{c}\text { Papers remaining after title } \\
\text { and abstract screening }\end{array}$ & $\begin{array}{c}\text { Papers remaining after } \\
\text { full text screening }\end{array}$ \\
\hline Association for Computing Machinery (ACM) & 29 & 15 & 1 \\
\hline IEEE Xplore & 7 & 5 & 3 \\
\hline ScienceDirect & 88 & 7 & 1 \\
\hline Scopus & 11 & 9 & 2 \\
\hline Wiley Online Library & 20 & 3 & 0 \\
\hline Emerald Insight & 4 & 1 & 0 \\
\hline SpringerLink & 35 & 10 & \\
\hline Sage Journals & 3 & 0 & \\
\hline Google Scholar & 9 & 6 & \\
\hline Total & $\mathbf{2 0 4}$ & $\mathbf{5 5}$ & \\
\hline
\end{tabular}


The eligibility criteria include both the search string and the exclusion criteria. The article screening process (as shown in Figure 2) aimed to ensure that the eligibility criteria are applied consistently to reduce the risk of introducing bias in an evidence synthesis.

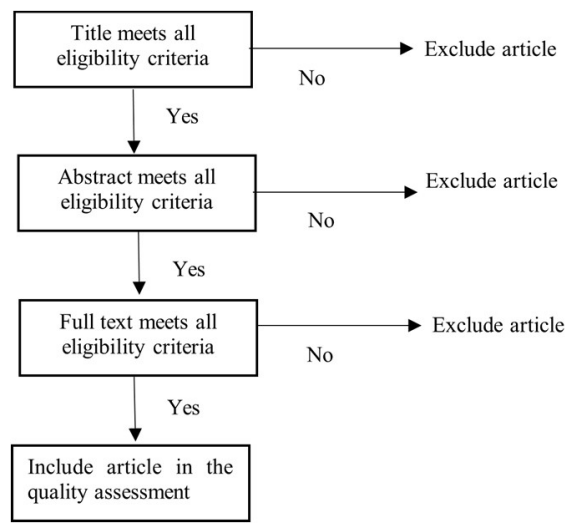

Figure 2. Eligibility screening process
The co-word (keywords co-occurrence) analysis using VOSViewer was then conducted to the selected 204 papers. The unit of analysis for co-word analysis was 'words' which were derived from authors' keywords (Donthu et al., 2021) using VOSViewer. A total of 545 keywords contained in 204 related papers have been analyzed. The emerged themes were the keywords with the greatest total link strength. The identified themes to focus on this review were organisational culture, agile software development, agile methodologies and agile. The keywords co-occurrence network visualization is as shown in Figure 3.

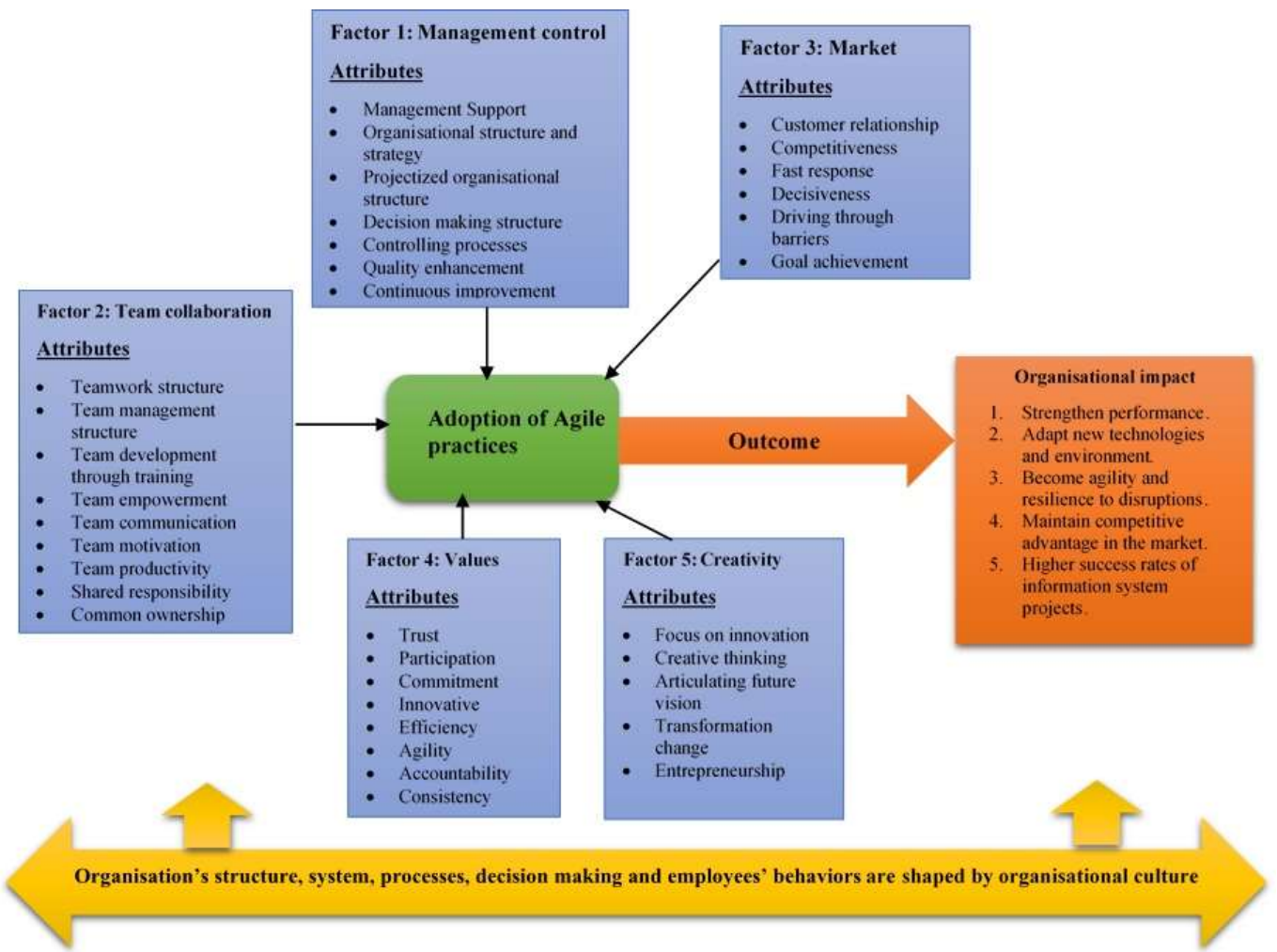

Figure 3. Organisational culture and agile practices adoption conceptual framework

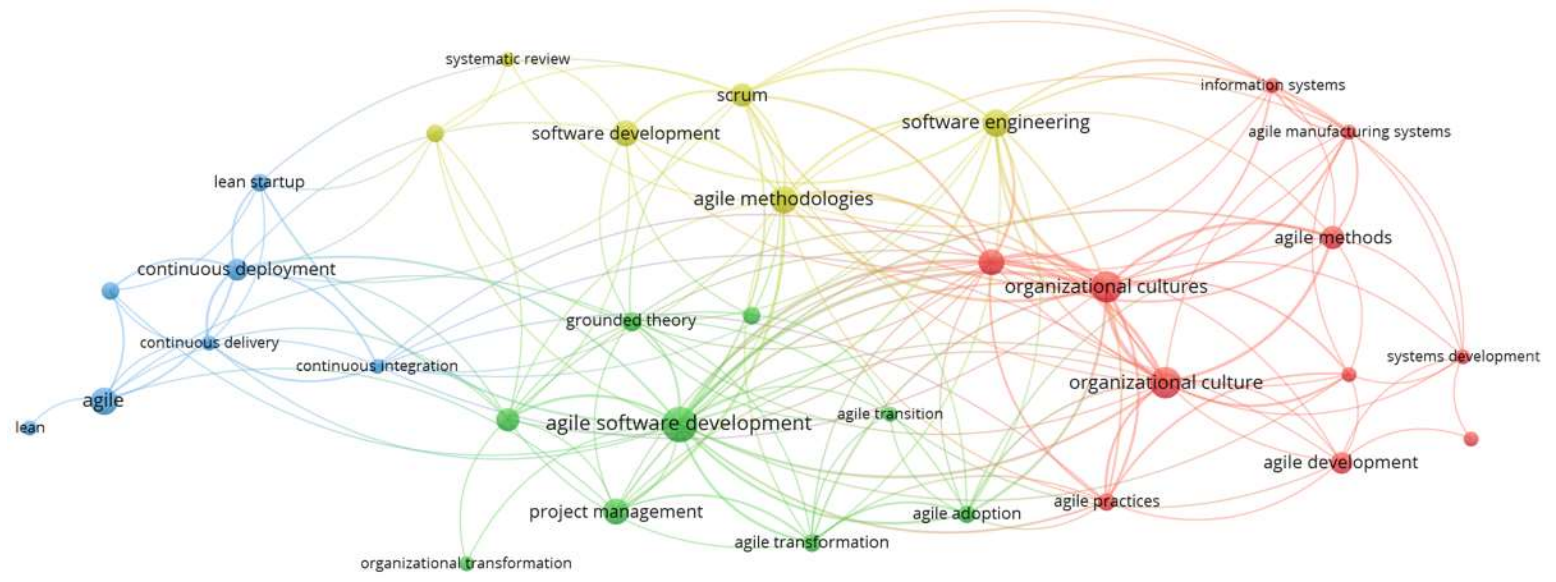

Figure 4. Keyword co-occurence network visualization (Year 2015-2020, n=204 papers) 
Two filters of articles were applied: (i) manual reading of titles and abstracts to remove articles which are clearly irrelevant; and (ii) assessment of the full-text version of the article. First, titles and abstracts of the 204 selected papers were then screened based on exclusion criteria to include or exclude papers. The term co-occurrence analysis was also conducted using VOSviewer where the unit of analysis were title and abstract. The analysis created a term of occurrence map based on text data where 2768 terms were extracted from title and abstract fields of 204 papers. The minimum number of occurrences of a term was 5 of the 2768 terms, 129 terms met threshold as shown in Figure 4 .

Fifty five papers remained after title and abstract screening. Second, these papers were examined based on the full text to identify papers focused on organisational culture influencing agile adoption. Nine papers remained after full text screening were subjected for study quality assessment. These papers were identified for quality assessment because they specific focus on linkage between organisational culture and agile practices in organisations. Thus, full texts of nine papers are aligned with the research question of this review.

\section{Step 4: Quality assessment criteria}

The quality assessment criteria were adapted from Dybå and Dingsøyr (2008) and Huff (1999). The nine primary studies (as shown in Appendix B) were assessed according to ten criteria as shown in Table 2.

Table 2. Quality assessment criteria

\begin{tabular}{|c|l|}
\hline$\#$ & Question \\
\hline Q1 & $\begin{array}{l}\text { Is the paper based on research (or is it merely a } \\
\text { "lessons learned" report based on expert opinion)? }\end{array}$ \\
\hline Q2 & Is there a clear statement of the aim(s) of the research? \\
\hline Q3 & $\begin{array}{l}\text { Is there an adequate description of the context in } \\
\text { which the research was carried out? }\end{array}$ \\
\hline Q4 & $\begin{array}{l}\text { Was the research design appropriate to address the } \\
\text { aims of the research? }\end{array}$ \\
\hline Q5 & Is the research methodology well presented? \\
\hline Q6 & $\begin{array}{l}\text { Was the data collected in a way that addressed the } \\
\text { research issue? }\end{array}$ \\
\hline Q7 & Was the data analysis sufficiently rigorous? \\
\hline Q8 & Is there a clear statement of findings? \\
\hline Q9 & Does the conclusion relate to the aim of the study? \\
\hline Q10 & Is the study of value for research or practice? \\
\hline
\end{tabular}

The ten criteria as shown in Table 2 were used to assess the quality of the primary studies which covered four main parts:

- Reporting: Three criteria (Q1-Q3) were related to the quality of the reporting of a study's rationale, aims, and context.

- Rigor: Five criteria (Q4-Q7) were related to the rigor of the research methods employed to establish the validity of data.

- Credibility: Two criteria (Q8-Q9) were related to the assessment of the credibility of the study methods for ensuring that the findings and conclusion were valid and meaningful.

- Relevance: The final criterion (Q10) was related to the assessment of the relevance of the study for the software industry at large and the research community.

The numerical scale numbered with 0 for "no", 1 for "partially" and 2 for "yes" was used to rank how well the questions were answered in each primary study. The detailed scores of the quality assessment for the primary studies are shown in the quality assessment checklist (Appendix B). The minimum score is 10 and if the primary study scored below 10, it is excluded. All nine papers scored more than 10 (as shown in Appendix B) which met the quality assessment criteria.

\section{Step 5: Data extraction}

A data extraction form was developed to extract data from the nine primary studies. The data extraction form is presented in Appendix C. The form is divided into three sections. The first section is for the study identification that has seven elements, the second section is for description of the study that has nine elements and quality assessment section that has one element. Study identification includes unique id for the study, title, author(s), publication year, type of article, volume/issue/page number and database.

Description of the study includes study aim(s), study objective(s), design of the study (surveys, case studies, theoretical and conceptual papers, literature reviews, modelling papers), research method (qualitative, quantitative, mixed research method), underlying theories/ frameworks/models, identified organisational culture attributes, findings and conclusion. The quality assessment includes the total score for paper quality. Data records were kept in Microsoft Excel for synthesizing the extracted data.

\section{Step 6: Data synthesis}

Data synthesis summarized and presented the findings of the nine primary studies in answering the research question. This phase is aimed at synthesizing the identified concepts and drawing a conclusion. The primary studies were analyzed and grouped into the identified organisational culture attributes which influence the adoption of agile practices. The following section presents the results.

\section{RESULTS}

Table 3 presents the identified organisational culture attributes from the primary studies which influence the adoption of agile practices.

Table 3. Organisational culture attributes identified from primary studies

\begin{tabular}{|c|c|c|}
\hline Factors & $\begin{array}{c}\text { Organisational culture } \\
\text { attributes }\end{array}$ & $\begin{array}{l}\text { Primary } \\
\text { studies }\end{array}$ \\
\hline $\begin{array}{l}\text { Management } \\
\text { control }\end{array}$ & $\begin{array}{ll}\text { - } & \text { Management support } \\
\text { - } & \text { Organisational } \\
\text { - } & \text { Projucture and strategy } \\
& \text { organisational } \\
& \text { structure } \\
\text { - } & \text { Decision making } \\
\text { - } & \text { Structure } \\
\text { - } & \text { Quntrolling processes } \\
\text { - } & \text { Continuous } \\
& \text { improvement }\end{array}$ & $\begin{array}{l}\text { Baham 2016; } \\
\text { Dikert et al. } \\
\text { 2016; Jivan et } \\
\text { al. } 2020\end{array}$ \\
\hline
\end{tabular}




\begin{tabular}{|c|c|c|}
\hline Factors & $\begin{array}{ll}- & \begin{array}{l}\text { Organisational } \\
\text { culture attributes }\end{array} \\
\end{array}$ & $\begin{array}{l}\text { Primary } \\
\text { studies }\end{array}$ \\
\hline Creativity & $\begin{array}{ll}\text { - } & \text { Focus on innovation } \\
\text { - } & \text { Creative thinking } \\
\text { - } & \text { Articulating future } \\
\text { vision } \\
\text { - } \quad \text { Transformation } \\
\text { change } \\
\text { - } \quad \text { Entrepreneurship } \\
\end{array}$ & $\begin{array}{l}\text { Baham 2016; } \\
\text { Othman et al. } \\
\text { 2016; Jivan et } \\
\text { al. } 2020\end{array}$ \\
\hline Market & $\begin{array}{ll}\text { - } & \text { Customer relationship } \\
\text { - } & \text { Competitiveness } \\
\text { - } & \text { Fast response } \\
\text { - } & \text { Decisiveness } \\
\text { - } & \text { Driving through } \\
& \text { barriers } \\
\text { - } & \text { Goal achievement }\end{array}$ & $\begin{array}{l}\text { Baham 2016; } \\
\text { Othman et al. } \\
\text { 2016; Jivan et } \\
\text { al. } 2020\end{array}$ \\
\hline Values & $\begin{array}{ll}\text { - } & \text { Trust } \\
\text { - } & \text { Participation } \\
\text { - } & \text { Commitment } \\
\text { - } & \text { Innovative } \\
\text { - Efficiency } \\
\text { - Agility } \\
\text { - Accountability } \\
\text { - } \text { Consistency } \\
\end{array}$ & $\begin{array}{l}\text { Gupta et al. } \\
\text { 2019; Othman } \\
\text { et al. 2016; } \\
\text { Soares \& } \\
\text { Brodbeck 2018; } \\
\text { Šmite et al. } \\
2020\end{array}$ \\
\hline
\end{tabular}

The identified organisational culture attributes are explained as:

\section{Management control}

Management control is a management function that helps implementing strategies to achieve organisational goals. Anthony and Govindarajan (2004:7) define management control as "the process by which managers influence other members of the organisation to implement the organisation's strategies." Management control can be viewed as a system which comprises of the organisational structure and strategy, organisational culture, core control practices and management information systems (Johnson \& Gill 1993; Heath 2001:94).

\section{Team collaboration}

A team consists of two or more individuals who work together interdependently with a shared vision to achieve some common goals. For instance, the project team is a cross-functional team from different departments in the organisation to implement project activities to achieve project objectives. Teamwork involves knowledge, attitude and skills (Xiao, Parker \& Mauser 2013). Knowledge should have team mission, objectives, problems, norms and resources. The skills define the behavior within the team such as coordination, performance evaluation, communication and cultural values among team members (Xiao et al. 2013).

\section{Market}

Market is externally oriented, and the organisational structure is strengthened by mechanisms of control to meet the stakeholders' expectations. To assist high levels of performance, clear objectives and reward systems are developed and put in place in the organisation.

\section{Values}

Values guide the organisation and support its vision, shape the organisational culture and impact the business strategy. Organisational values provide the guiding principles of the organisation's culture that determine employees' behaviors and organisational success (Hofstede 2001).

\section{Creativity}

Creativity has been used by organisations to generate new ideas to add value to their products or services as well as problem solving. Employees in the organisation spearhead the creativity processes to retain its competitive advantage in the market (Parjanen 2012). There are various characteristics in the organisation that support employees' creativity such as organisational strategy which focuses on innovation, leadership and organisational culture.

Based on the above explanations, the organisational culture attributes which have influence on agile adoption are summarized as shown in Figure 5.

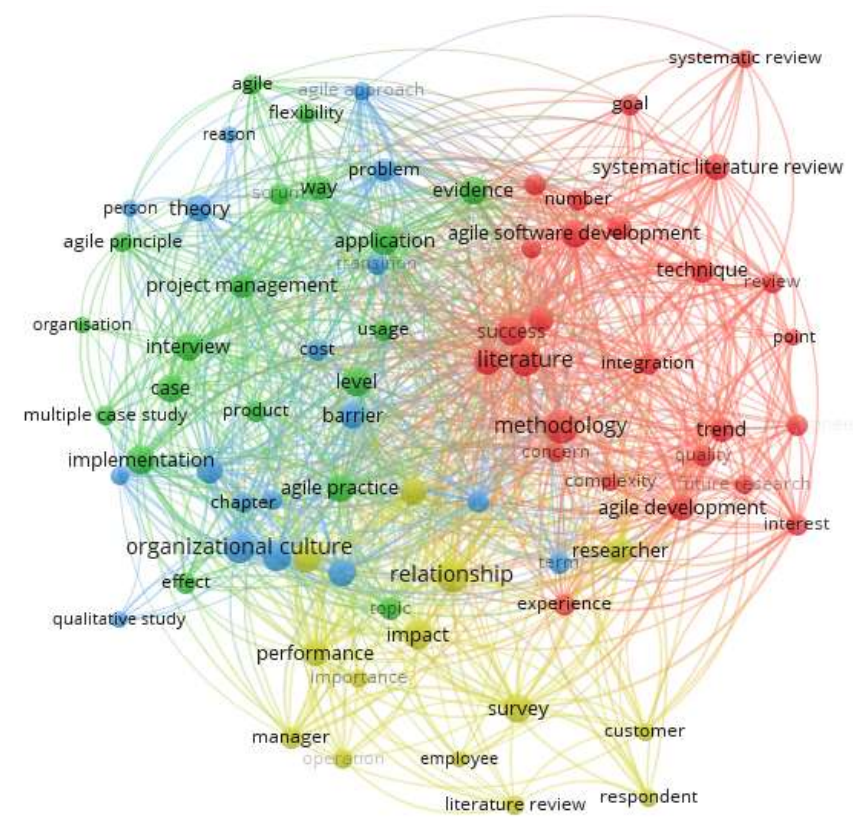

Figure 5. Term co-occurrence network visualization $(n=204)$

\section{DISCUSSION}

Organisations have been adopting agile practices to deliver information system projects faster and create business value. Despite its advantages, many organisations battle to successfully adopt agile practices. While there are several challenges for agile adoption, organisational culture has been amongst the challenges on adopting agile practices. This systematic literature review presented the findings of the nine selected primary studies on influences of organisational culture on the adoption of agile practices. The analysis of the primary studies showed that management control, team collaboration, creativity, market and values (as illustrated in Table 3) are important factors with attributes that influence the adoption of agile practices. Organisational culture has been used as a tool for management to control, motivate and enhance employees' performance in the organisation (Oweyemi \& Ekwoaba 2014). Thus, management 
control ensures the achievement of organisation's objectives and goals. This research identified the organisational culture attributes which influence the adoption of agile practices that focused in the management control as: management support, organisational structure, projectized organisational structure, decision making structure, controlling processes, quality enhancement and continuous improvement (Baham 2016; Dikert et al. 2016; Jivan et al. 2020). Team collaboration included organisational culture attributes which influence the adoption of agile practices such as teamwork structure, team management structure, team development through training, team empowerment, team communication, team motivation, team productivity, shared responsibility and common ownership (Baham 2016; Dikert et al. 2016; Ghimire et al. 2020; Gregory \& Taylor 2019; Jivan et al. 2020 ). For creativity, this research identified a number of organisational culture attributes which influence the adoption of agile practices as: focus on innovation, creative thinking, articulating future vision, transformation change and entrepreneurship (Baham 2016; Othman et al. 2016; Jivan et al. 2020). The research also identified organisational culture attributes which influence the adoption of agile practices that focused on market as customer relationship, competitiveness, fast response, decisiveness, driving through barriers and goal achievement (Baham 2016; Othman et al. 2016; Jivan et al. 2020). The present research identified several organisational culture attributes which influence the adoption of agile practices that focused on values as: trust, participation, commitment, innovative, efficiency, agility, accountability and consistency (Gupta et al. 2019; Othman et al. 2016; Šmite et al. 2020; Soares \& Brodbeck 2018). The findings of this study indicated that an organisation's structure, system, processes, decision making and employees' behaviors are shaped by organisational culture (Suda 2007). The organisation with strong organisational culture tends to strengthen their performance, adapt to new technologies and environment, become agility and resilience to disruptions as well as maintaining their competitive advantage in the market. Information systems projects that are aligned with organisational culture have higher success rates (Suda 2007).

The review protocol was adapted to ensure the validity of the study. The number of databases were searched using the search string to retrieve relevant studies on how organisational culture influences the adoption of agile practices. Threats to publication bias were covered by including only the published papers in the period under review (2015-2020). The findings and conclusion are reviewed by the authors and improvement were made.

\section{CONCLUSION}

This study presented the systematic literature review of the organisational culture attributes which influence the adoption of agile practices.

\section{Contributions of the Study}

First, the theoretical contribution of this study is to provide organisational culture attributes which can be used by organisations to adopt agile practices. Second, this study contributes to the body of knowledge in agile project management by providing project management practitioners with attributes for organisational culture that influence the adoption of agile. The results of the systematic literature review presented in this study will benefit researchers and project management practitioners.

\section{Limitations of the Study}

This study was limited because of the small sample size (five years) covered from January 2015 to December 2020. Further research is needed to collected data in a larger sample size (more than five years to understand how organisational culture influences the adoption of agile practices. Other limitation is most of the selected primary studies applied competing value framework which is specific for organisational culture but did not develop a new conceptual framework. The search criteria did not include proportion of countries with research in the area, this is among the limitations of this study.

\section{Future Research}

The future research will detail the proportion of countries with research in the area and the period with the greatest dissemination and visibility of the studies. Further research will also develop a new framework that integrate organisational culture and the adoption of agile practices.

Authors' contributions: All authors contributed equally to this work. Funding: No funding is provided for this article.

Declaration of interest: The authors declare that they have no competing interests.

Data availability: The authors confirm that the data supporting the findings of this study are available for sharing when requested to authors.

\section{REFERENCES}

Anthony, R. N. and Govindarajan, V. (2004). Management Control Systems, $11^{\text {th }}$ ed. New York: McGraw Hill/Irwin.

Anwar, A., Kamel, A. \& Ahmed, E. (2016). Agile Adoption Case Study, Pains, Challenges \& Benefits: proceedings of the $2^{\text {nd }}$ Africa and Middle East Conference on Software Engineering, proceedings, Cairo, Egypt, May, 2016.

Baham, C. (2016). The Impact of Organisational Culture and Structure on the Routinization of Agile Software Development Methodologies. Available at: https://aisel.aisnet.org/amcis2016/ITProj/Presentations/29/. (Accessed 20 August 2020).

Beck. K., Beedle, M., Bennekum, A., Cunningham, W., Fowler, M., Grenning, J., Highsmith, J., Hunt, A., Jeffries, R., Kern, J., Marick, B., Martin, R.C., Mellor, S., Schwaber, K., Sutherland, J. and Thomas, D. (2010). The Agile Manifesto. Agile Alliance. Available at: http://agilemanifesto.org/. (Accessed 22 August 2020).

Dikert, K., Paasivaara, M. and Lassenius, C. (2016). Challenges and Success Factors for Large-scale Agile Transformations - A Research Proposal and a Pilot Study. Journal of Systems and Software, 119, 87-108. https://doi.org/10.1016/j.jss.2016.06.013.

Dybå, T. and Dingsøyr, T. (2008). Strength of Evidence in Systematic Reviews in Software Engineering: proceedings of the ACM-IEEE International Symposium on Empirical Software Engineering and Measurement, Kaiserslautern, Germany, October, 2008.

Gusenbauer, M. and Haddaway, N. R. (2019). Which academic 
search systems are suitable for systematic reviews or metaanalyses? Evaluating retrieval qualities of Google Scholar, PubMed, and 26 other resources. Research Synthesis Method, 11(2), 181-217. https://doi.org/10.1002/jrsm.1378.

Genç, K. Y. (2013). Culture as a strategic resource for organizations and an assessment on cultures of Turkish large firms: proceedings of the $2^{\text {nd }}$ International Conference on Leadership, Technology and Innovation Management, Istanbul, Turkey, October 11-13.

Ghimire, D., Charters, S. and Gibbs, S. (2020). Scaling Agile Software Development Approach in Government Organisation in New Zealand: proceedings of the 3rd International Conference on Software Engineering and Information Management, proceedings, Sydney, NSW, Australia, January 12-15.

Gregory, P. and Taylor, K. (2019). Defining Agile Culture: A Collaborative and Practitioner-Led Approach: proceedings of the IEEE/ACM 12 $12^{\text {th }}$ International Workshop on Cooperative and Human Aspects of Software Engineering (CHASE), proceedings, Montreal Quebec, Canada, May.

Gupta, M. (2018). Relationships between IT department culture and agile software development practices: An empirical investigation. International Journal of Information Management, 44 (2019), 13-24. https://doi.org/10.1016/j.ijinfomgt.2018.09.006.

Herath, S.K. (2001). Patterns of management control in a family managed business in an emerging economy: the case of Dilham Tea in Sri Lanka. Available at: https://ro.uow.edu.au/theses/1024/. (Accessed 22 August 2020).

Hofstede, G. (2001). Culture consequences: Comparing values, behaviors, institutions and organisations across nations, $2^{\text {nd }}$ ed. Thousand Oaks, CA: Sage Publication Inc.

Huff, A.S. (1999). Writing for Scholarly Publication. Thousand Oaks, CA: Sage Publication Inc.

Johnson, P. and Gill, J. (1993). Management Control and Organisational Behaviour. London: Paul Chapman.

Jivan, K.P., Marnewick, A, L. and Joseph, N. (2020). Influences of organisational culture in the agile adoption: proceedings of the IEEE Technology and Engineering Management Conference (TEMSCON), proceedings, Metro Detroit, Michigan, June 3-6.

Kitchenham, B., Brereton, O., Budgen, D., Turner, M., Bailey, J. and Linkman, S. (2009). Systematic literature reviews in software engineering - A systematic literature review. Information and Software Technology, 51 (1), 7-15.

Kgoroeadira, R. (2010. Promoting entrepreneurship as a means to foster economic development: a review of market failure and public policy. Available at: https:/dspace.lib.cranfield.ac.uk/bitstream/handle/1826/69 01/Kgoroeadira_Reabetswe_Thesis_2010.pdf;sequence=1. (Accessed 12 August 2020).

Othman, H. B., Zouaoui. M and Hamdoun, M. (2016). Organisational culture and the acceptance of agile methodology: proceedings of the IEEE International Conference on Digital Economy (ICDEc), proceedings, Carthage, Tunisia, April 28-30.

Oweyemi. O. and Ekwoaba. J.O. (2014). Organisational Culture: A Tool for Management to control, motivate and enhance employees' performance. American Journal of Business and Management, 3 (3), 168-177.
Parjanen, S. (2012). Experiencing creativity in the organisation: From individual creativity to collective creativity. Interdisciplinary Journal of Information, Knowledge and Management, 7, 109-128.

PMI Pulse of the Profession. (2017). PMI pulse of the profession, 9th global project survey: Success rates rise, transforming the high cost of low performance. Newton Square, PA: Project Management Institute.

Pinto, J. K. (2010). Project management: achieving competitive advantage, 2nd ed. Prentice Hall: New Jersey.

Raharjo, T. and Purwandari, B. (2020). Agile Project Management Challenges and Mapping Solutions: A Systematic Literature Review: proceedings of the $3^{\text {rd }}$ International Conference on Software Engineering and Information Management, proceedings, Sydney, NSW, Australia, January 12-15.

Scopus. (2020). Discover why the world's leading researchers and organizations choose Scopus. Available at: https://www.elsevier.com/solutions/scopus/why-choosescopus.(Accessed 12 August 2020).

Šmite, D., Gonzalez-Huerta, J. and Moe, B. N. (2020). When in Rome, Do as the Romans Do: Cultural Barriers to Being Agile in Distributed Teams: proceedings of the 21st International Conference on Agile Software Development, XP 2020, Copenhagen, Denmark, June 8-12.

Soares, L.P. and Brodbeck, A.F. (2018). For Some Places More Than Others - Agility and Organisational Culture, V. A. Santos et al. (Eds.): WBMA 2017, CCIS 802, pp. 121-133.

Strode, D.E., Huff, S.L. and Tretiakov, A. (2009). The Impact of Organisational Culture on Agile Method Use: proceedings of the $42^{\text {nd }}$ Hawaii International Conference on System Sciences, Waikoloa, Hawaii, 5-8 January.

Suda, L. V. (2007). The meaning and importance of culture for project success: proceedings of the PMI ${ }^{\circledR}$ Global Congress, EMEA, Budapest, Hungary.

VersionOne. (2020). 14 $4^{\text {th }}$ Annual of state of agile report. Available at: https://explore.digital.ai/state-of-agile/14th-annualstate-of-agile-report. (Accessed 17 September 2020).

Xiao, Y., Parker, S.H. and Manser, T. (2013). Teamwork and collaboration. Reviews of human factors and ergonomics, 8 (1), 55 - 102. https://doi.org/10.1177/1557234X13495181.

\section{Appendix A: List of primary studies}

Baham, C. (2016). The Impact of Organisational Culture and Structure on the Routinization of Agile Software Development Methodologies. Available at: https://aisel.aisnet.org/amcis2016/ITProj/Presentations/29/. (Accessed 26 August 2020).

Dikert, K., Paasivaara, M. and Lassenius, C. (2016). Challenges and Success Factors for Large-scale Agile Transformations - A Research Proposal and a Pilot Study. Journal of Systems and Software, 119, 87-108. https://doi.org/10.1016/j.jss.2016.06.013.

Ghimire, D., Charters, S. and Gibbs, S. (2020). Scaling Agile Software Development Approach in Government Organisation in New Zealand: proceedings of the $3^{\text {rd }}$ International Conference on Software Engineering and Information Management, Sydney, NSW, Australia, January 12-15. 
Gregory, P. and Taylor, K. (2019). Defining Agile Culture: A Collaborative and Practitioner-Led Approach: proceedings of the IEEE/ACM 12th International Workshop on Cooperative and Human Aspects of Software Engineering (CHASE), Montreal Quebec, Canada, May, 2019.

Gupta, M. (2018). Relationships between IT department culture and agile software development practices: An empirical investigation. International Journal of Information Management, 44 (2019), 13-24. https://doi.org/10.1016/j.ijinfomgt.2018.09.006.

Jivan, K.P., Marnewick, A, L. and Joseph, N. (2020). Influences of organisational culture in the agile adoption: proceedings of the IEEE Technology and Engineering Management Conference (TEMSCON), Metro Detroit, Michigan, June 36.

\section{Appendix B: Quality Assessment Checklist}

(Scale: 0 is "No", 1 is "Partially" and 2 is "Yes". Minimum total score is 10)
Othman, H. B., Zouaoui. M and Hamdoun, M. (2016). Organisational culture and the acceptance of agile methodology: proceedings of the IEEE International Conference on Digital Economy (ICDEc), Carthage, Tunisia, April 28-30.

Soares, L.P. and Brodbeck, A.F. (2018). For Some Places More Than Others - Agility and Organisational Culture, V. A. Santos et al. (Eds.): WBMA 2017, CCIS 802, pp. 121-133.

Šmite, D., Gonzalez-Huerta, J. and Moe, B. N. (2020). When in Rome, Do as the Romans Do: Cultural Barriers to Being Agile in Distributed Teams: proceedings of the $21^{\text {st }}$ International Conference on Agile Software Development, XP 2020, Copenhagen, Denmark, June 8-12.

\begin{tabular}{|c|c|c|c|c|c|c|c|c|c|c|c|c|c|}
\hline \multirow[b]{2}{*}{ Paper \# } & \multirow[b]{2}{*}{ Reference } & \multicolumn{3}{|c|}{ Quality of Reporting } & \multicolumn{4}{|c|}{ Rigor } & \multicolumn{2}{|c|}{ Credibility } & \multirow{2}{*}{$\begin{array}{c}\text { Relevance } \\
\text { Q10 }\end{array}$} & \multirow{2}{*}{$\begin{array}{l}\text { Total } \\
\text { Score }\end{array}$} & \multirow[b]{2}{*}{ Rank } \\
\hline & & Q1 & Q2 & Q3 & Q4 & Q5 & Q6 & Q7 & Q8 & Q9 & & & \\
\hline P1 & Dikert et al. 2016 & 2 & 2 & 1 & 1 & 2 & 2 & 1 & 2 & 1 & 1 & 15 & 4 \\
\hline P2 & Gregory \& Taylor 2019 & 2 & 1 & 1 & 2 & 2 & 1 & 1 & 1 & 1 & 1 & 13 & 5 \\
\hline P3 & Jivan et al. 2020 & 2 & 2 & 1 & 2 & 2 & 2 & 2 & 2 & 1 & 1 & 17 & 2 \\
\hline P4 & Ghimire et al. 2020 & 2 & 2 & 2 & 1 & 1 & 2 & 2 & 2 & 1 & 1 & 16 & 3 \\
\hline P5 & Gupta 2018 & 2 & 1 & 1 & 2 & 1 & 1 & 1 & 1 & 1 & 1 & 12 & 6 \\
\hline P6 & Soares \& Brodbeck 2018 & 2 & 2 & 2 & 2 & 1 & 1 & 1 & 2 & 2 & 2 & 17 & 2 \\
\hline P7 & Šmite et al. 2020 & 2 & 1 & 1 & 2 & 2 & 1 & 1 & 1 & 1 & 1 & 13 & 5 \\
\hline P8 & Othman et al. 2016 & 2 & 2 & 1 & 2 & 2 & 2 & 1 & 2 & 2 & 2 & 18 & 1 \\
\hline P9 & Baham 2016 & 2 & 2 & 2 & 2 & 1 & 1 & 1 & 2 & 2 & 2 & 17 & 2 \\
\hline
\end{tabular}




\section{Appendix C: Data Extraction Form}

\begin{tabular}{|c|c|c|c|c|c|c|c|c|c|}
\hline \multicolumn{10}{|c|}{ Section A: Study Identification } \\
\hline $\begin{array}{l}\text { Unique ID for the } \\
\text { study }\end{array}$ & P1 & P2 & P3 & P4 & P5 & P6 & P7 & P8 & P9 \\
\hline Title & $\begin{array}{l}\text { Challenges and } \\
\text { Success Factors for } \\
\text { Large-scale Agile } \\
\text { Transformations - A } \\
\text { Research Proposal } \\
\text { and a Pilot Study }\end{array}$ & $\begin{array}{l}\text { Defining Agile } \\
\text { Culture: A } \\
\text { Collaborative and } \\
\text { Practitioner-Led } \\
\text { Approach }\end{array}$ & $\begin{array}{l}\text { Influences of } \\
\text { organisational } \\
\text { culture in the } \\
\text { agile adoption }\end{array}$ & $\begin{array}{l}\text { Scaling Agile Software } \\
\text { Development Approach } \\
\text { in Government } \\
\text { Organisation in New } \\
\text { Zealand }\end{array}$ & $\begin{array}{l}\text { Relationships } \\
\text { between IT } \\
\text { department } \\
\text { culture and agile } \\
\text { software } \\
\text { development } \\
\text { practices: An } \\
\text { empirical } \\
\text { investigation } \\
\end{array}$ & $\begin{array}{l}\text { For some } \\
\text { places more } \\
\text { than others - } \\
\text { Agility and } \\
\text { organisational } \\
\text { culture }\end{array}$ & $\begin{array}{l}\text { "When in Rome, } \\
\text { Do as the } \\
\text { Romans Do": } \\
\text { Cultural Barriers } \\
\text { to Being Agile in } \\
\text { Distributed } \\
\text { Teams }\end{array}$ & $\begin{array}{l}\text { Organisational } \\
\text { culture and the } \\
\text { acceptance of } \\
\text { agile } \\
\text { methodology }\end{array}$ & $\begin{array}{l}\text { The Impact of } \\
\text { Organisational Culture } \\
\text { and Structure on the } \\
\text { Routinization of Agile } \\
\text { Software Development } \\
\text { Methodologies }\end{array}$ \\
\hline Author (s) & $\begin{array}{l}\text { Kim Dikert, Maria } \\
\text { Paasivaara and } \\
\text { Casper Lassenius }\end{array}$ & $\begin{array}{l}\text { Peggy Gregory } \\
\text { and Katie Taylor }\end{array}$ & $\begin{array}{l}\text { Jivan, K.P., } \\
\text { Marnewick, } \\
\text { A.L., and } \\
\text { Joseph, N. }\end{array}$ & $\begin{array}{l}\text { Dipendra Ghimire, } \\
\text { Stuart Charters, and } \\
\text { Shirley Gibbs }\end{array}$ & $\begin{array}{l}\text { Manjul Gupta, } \\
\text { Joey F. Georgeb, } \\
\text { Weidong Xia }\end{array}$ & $\begin{array}{l}\text { Soares, L.P., } \\
\text { and Brodbeck, } \\
\text { Â.F }\end{array}$ & $\begin{array}{l}\text { Darja Šmite, } \\
\text { Javier Gonzalez- } \\
\text { Huerta, Nils } \\
\text { Brede Moe }\end{array}$ & $\begin{array}{l}\text { Hanen Ben } \\
\text { Othman ; Mahmo } \\
\text { ud } \\
\text { Zouaoui ; Moham } \\
\text { ed Hamdoun }\end{array}$ & Corey Baham \\
\hline Publication year & 2016 & 2019 & 2020 & 2020 & 2019 & 2018 & 2020 & 2016 & 2016 \\
\hline Type of article & Journal article & Conference paper & $\begin{array}{l}\text { Conference } \\
\text { paper }\end{array}$ & Conference paper & Journal article & $\begin{array}{l}\text { Conference } \\
\text { paper }\end{array}$ & $\begin{array}{l}\text { Conference } \\
\text { paper }\end{array}$ & Conference paper & Conference paper \\
\hline $\begin{array}{l}\text { Volume/issue/pag } \\
\text { e number }\end{array}$ & $\begin{array}{l}\text { Volume 119, pp. 87- } \\
108\end{array}$ & & & pp. 100-104 & $\begin{array}{l}\text { Volume } 44, \text { pp. } 13- \\
24\end{array}$ & pp. 121-133 & pp. $145-161$ & pp. 16-23 & pp.29 \\
\hline Database & ScienceDirect & IEEE Xplore & IEEE Xplore & $\begin{array}{l}\text { Association for } \\
\text { Computing Machinery } \\
\text { (ACM) Digital Library }\end{array}$ & Scopus & Scopus & SpringerLink & IEEE Xplore & Google Scholar \\
\hline \multicolumn{10}{|c|}{ Section B: Study Description } \\
\hline Study aim(s) & $\begin{array}{l}\text { To understand the } \\
\text { identified challenges } \\
\text { and success factors of } \\
\text { large-scale agile } \\
\text { transformations by } \\
\text { targeting a larger } \\
\text { population of } \\
\text { companies }\end{array}$ & $\begin{array}{l}\text { To explore how a } \\
\text { group took a } \\
\text { collaborative and } \\
\text { practitioner-led } \\
\text { approach to } \\
\text { developing a } \\
\text { definition of Agile } \\
\text { Culture and a set } \\
\text { of tools to aid } \\
\text { cultural } \\
\text { assessment }\end{array}$ & $\begin{array}{l}\text { To investigate } \\
\text { the influence of } \\
\text { organisational } \\
\text { culture in the } \\
\text { adoption of } \\
\text { agile }\end{array}$ & $\begin{array}{l}\text { To investigate the } \\
\text { factors that are } \\
\text { important in the public } \\
\text { sector for a successful } \\
\text { project and compares } \\
\text { against results for the } \\
\text { private sector }\end{array}$ & $\begin{array}{l}\text { To examine the } \\
\text { relationships } \\
\text { between four } \\
\text { competing } \\
\text { cultural forms and } \\
\text { two types of agile } \\
\text { practices - social } \\
\text { and technical }\end{array}$ & $\begin{array}{l}\text { To explore the } \\
\text { relationship } \\
\text { between } \\
\text { selected basic } \\
\text { cultural } \\
\text { assumptions } \\
\text { of } \\
\text { organisations } \\
\text { and agile } \\
\text { practices }\end{array}$ & $\begin{array}{l}\text { To explore re the } \\
\text { cultural barriers } \\
\text { impeding agile } \\
\text { ways of working } \\
\text { in distributed } \\
\text { teams with } \\
\text { members from a } \\
\text { hierarchical } \\
\text { culture }\end{array}$ & $\begin{array}{l}\text { To understand } \\
\text { how culture can } \\
\text { influence on the } \\
\text { acceptance of } \\
\text { agile } \\
\text { methodology } \\
\text { within Tunisian } \\
\text { enterprises in the } \\
\text { software } \\
\text { development } \\
\text { sector }\end{array}$ & $\begin{array}{l}\text { To contribute to the } \\
\text { current body of Agile } \\
\text { Software Development } \\
\text { (ASD) research by } \\
\text { providing an } \\
\text { understanding of gap } \\
\text { between perceived ASD } \\
\text { success (at acceptance) } \\
\text { and ASD routinization }\end{array}$ \\
\hline
\end{tabular}


Mkoba / J INFORM SYSTEMS ENG, 7 (1), 11690

\begin{tabular}{|c|c|c|c|c|c|c|c|c|c|}
\hline Study objective(s) & $\begin{array}{l}\text { To validate and } \\
\text { deepen findings from } \\
\text { the literature review }\end{array}$ & $\begin{array}{l}\text { To provide an } \\
\text { overview of the } \\
\text { development } \\
\text { process used by } \\
\text { a practitioner-led } \\
\text { collaborative } \\
\text { team to develop } \\
\text { a definition of } \\
\text { Agile culture }\end{array}$ & $\begin{array}{l}\text { To describe the } \\
\text { culture that is } \\
\text { conducive to the } \\
\text { realization of the } \\
\text { benefits of agile }\end{array}$ & $\begin{array}{l}\text { This study } \\
\text { compares the } \\
\text { main challenges in } \\
\text { the public and the } \\
\text { private sector }\end{array}$ & $\begin{array}{l}\text { To determine how } \\
\text { does IT } \\
\text { department } \\
\text { culture affect the } \\
\text { use of social and } \\
\text { technical agile } \\
\text { practices }\end{array}$ & $\begin{array}{l}\text { Correlation } \\
\text { between the } \\
\text { cultural } \\
\text { dimensions } \\
\text { researched } \\
\text { and selected } \\
\text { agile practices }\end{array}$ & $\begin{array}{l}\text { To explore what } \\
\text { are the specific } \\
\text { cultural barriers, } \\
\text { what resulting } \\
\text { behaviours } \\
\text { impede agility, } \\
\text { and whether these } \\
\text { behaviours prevail } \\
\text { among offshore } \\
\text { engineers working } \\
\text { in distributed } \\
\text { agile teams }\end{array}$ & $\begin{array}{l}\text { To identify critical } \\
\text { factors that affect } \\
\text { the acceptance of } \\
\text { agile methods, } \\
\text { and to analyze the } \\
\text { influence of } \\
\text { organisational } \\
\text { culture on the } \\
\text { acceptance of the } \\
\text { Agile } \\
\text { methodology } \\
\text { toward users }\end{array}$ & $\begin{array}{l}\text { To articulate a model that } \\
\text { explains the impact of } \\
\text { organisational culture and } \\
\text { structure on the } \\
\text { routinization of agile } \\
\text { methods }\end{array}$ \\
\hline $\begin{array}{l}\text { Design of the } \\
\text { study }\end{array}$ & Survey & $\begin{array}{l}\text { Interviews, } \\
\text { observation, } \\
\text { document } \\
\text { review, and } \\
\text { personal } \\
\text { reflections }\end{array}$ & Case study & Survey & Survey & $\begin{array}{l}\text { Survey, Case } \\
\text { study }\end{array}$ & Case study & Interview & Documents review \\
\hline Research method & Quantitative & Qualitative & Quantitative & Mixed method & Quantitative & Quantitative & Mixed method & Qualitative & Qualitative \\
\hline $\begin{array}{l}\text { Underlying } \\
\text { theories/ } \\
\text { frameworks/mode } \\
\text { ls }\end{array}$ & None & $\begin{array}{l}\text { Bronstein's } \\
\text { Interdisciplinary } \\
\text { Collaboration } \\
\text { Model }\end{array}$ & $\begin{array}{l}\text { Competing } \\
\text { Value } \\
\text { Framework }\end{array}$ & None & $\begin{array}{l}\text { Competing values } \\
\text { model }\end{array}$ & $\begin{array}{l}\text { Adapted } \\
\text { Schein's } \\
\text { Model of } \\
\text { organisational } \\
\text { culture }\end{array}$ & None & $\begin{array}{l}\text { Competing values } \\
\text { framework for } \\
\text { organisational } \\
\text { culture }\end{array}$ & $\begin{array}{l}\text { Competing values } \\
\text { framework for } \\
\text { organisational culture and } \\
\text { theoretical model }\end{array}$ \\
\hline Data collection & Questionnaire & Interviews & Questionnaire & $\begin{array}{l}\text { Questionnaire and } \\
\text { interview }\end{array}$ & Questionnaires & Questionnaire & $\begin{array}{l}\text { Questionnaire and } \\
\text { Interviews }\end{array}$ & Interviews & Literature review \\
\hline $\begin{array}{l}\text { Identified } \\
\text { organisational } \\
\text { culture attributes }\end{array}$ & $\begin{array}{l}\text { Management support; } \\
\text { Providing training on } \\
\text { agile methods; } \\
\text { Showing strong } \\
\text { commitment to the } \\
\text { transformation; } \\
\text { Creating and } \\
\text { communicating } \\
\text { positive experiences } \\
\text { in the beginning. }\end{array}$ & $\begin{array}{l}\text { Behaviour, } \\
\text { norms and } \\
\text { mindset }\end{array}$ & $\begin{array}{l}\text { Market, clan, } \\
\text { adhocracy, } \\
\text { hierarchy }\end{array}$ & $\begin{array}{l}\text { Self-managing } \\
\text { teams with shared } \\
\text { responsibility, } \\
\text { development team } \\
\text { with common } \\
\text { ownership }\end{array}$ & $\begin{array}{l}\text { Governance and } \\
\text { implementation } \\
\text { plan, behaviour, } \\
\text { values, } \\
\text { understand } \\
\text { cultural profiles of } \\
\text { stakeholder, } \\
\text { develop a shared } \\
\text { cultural profiles, } \\
\text { communication }\end{array}$ & $\begin{array}{l}\text { Pragmatism, } \\
\text { Favors } \\
\text { communicatio } \\
\mathrm{n} \text { and } \\
\text { participative. }\end{array}$ & $\begin{array}{l}\text { Behaviour, trust, } \\
\text { transparency }\end{array}$ & $\begin{array}{l}\text { Group culture, } \\
\text { development } \\
\text { culture, } \\
\text { hierarchical } \\
\text { culture and } \\
\text { rational culture }\end{array}$ & $\begin{array}{l}\text { Organisational culture } \\
\text { dimensions are } \\
\text { organisational strategy, } \\
\text { organisational structure, } \\
\text { artifacts and values, project } \\
\text { scope, team management } \\
\text { structure, decision making } \\
\text { structure, team work } \\
\text { structure, control mode. } \\
\text { Developmental and } \\
\text { hierarchical organisational } \\
\text { culture }\end{array}$ \\
\hline
\end{tabular}


Mkoba / J INFORM SYSTEMS ENG, 7 (1), 11690

\begin{tabular}{|c|c|c|c|c|c|c|c|c|c|}
\hline Findings & $\begin{array}{l}\text { The top success } \\
\text { factors for Large-scale } \\
\text { agile transformation } \\
\text { include: ensure } \\
\text { management support } \\
(29 \%) \text { and coach } \\
\text { teams as they learn by } \\
\text { doing }(29 \%) \text {, and } \\
\text { customize the agile } \\
\text { approach carefully } \\
(26 \%) .\end{array}$ & $\begin{array}{l}\text { Collective } \\
\text { ownership of } \\
\text { goals refers to } \\
\text { shared } \\
\text { responsibility for } \\
\text { goals }\end{array}$ & $\begin{array}{l}\text { The most } \\
\text { dorminant type } \\
\text { of culture is of a } \\
\text { market culture } \\
\text { ( } 31 \%) \text {, followed } \\
\text { by clan culture } \\
\text { ( } 26 \%) \text {, then } \\
\text { adhocracy } \\
\text { culture ( } 24 \%) \\
\text { and finally is } \\
\text { hierarchy } \\
\text { culture }(19 \%) \text {. }\end{array}$ & $\begin{array}{l}\text { Successful Agile } \\
\text { development } \\
\text { teams require } \\
\text { product } \\
\text { ownership both } \\
\text { from within the } \\
\text { team and within } \\
\text { the organisation } \\
\text { that understands } \\
\text { and supports the } \\
\text { iterative nature of } \\
\text { the Agile process }\end{array}$ & $\begin{array}{l}\text { Found a } \\
\text { significant positive } \\
\text { relationship } \\
\text { between rational } \\
\text { culture and social } \\
\text { agile practices } \\
\text { usage }\end{array}$ & $\begin{array}{l}\text { "Pragmatism", } \\
\text { "Favors } \\
\text { communicatio } \\
\mathrm{n} \text { " and } \\
\text { "participative" } \\
\text { are the ones } \\
\text { that correlate } \\
\text { more with } \\
\text { agile practices. } \\
\text { These cultural } \\
\text { dimensions } \\
\text { are aligned } \\
\text { with the four } \\
\text { values of the } \\
\text { Agile } \\
\text { Manifesto }\end{array}$ & $\begin{array}{l}\text { Found that culture } \\
\text { of the outsourcing } \\
\text { vendor did not } \\
\text { confirm with the } \\
\text { highlighted values } \\
\text { and management } \\
\text { style }\end{array}$ & $\begin{array}{l}\text { The results } \\
\text { revealed three } \\
\text { types of culture } \\
\text { noted; group } \\
\text { culture, } \\
\text { development } \\
\text { culture and } \\
\text { rational culture } \\
\text { promote the } \\
\text { acceptance of agile } \\
\text { methodology }\end{array}$ & $\begin{array}{l}\text { Hierarchical Organisational } \\
\text { Culture tends to restrict } \\
\text { team autonomy through } \\
\text { rigid formal controls, the } \\
\text { arrangement of skill-based } \\
\text { versus team-based working } \\
\text { structures, the subjection to } \\
\text { both project managers and } \\
\text { functional managers, and } \\
\text { the top-down decision- } \\
\text { making structures that } \\
\text { disrupt a team's ability to } \\
\text { development unique } \\
\text { solutions to complex issues }\end{array}$ \\
\hline Conclusion & $\begin{array}{l}\text { The study identified a } \\
\text { set of challenges and } \\
\text { success factors. To } \\
\text { validate and deepen } \\
\text { our findings from the } \\
\text { literature review and } \\
\text { to understand the } \\
\text { completeness of the } \\
\text { identified factors, we } \\
\text { plan to conduct a } \\
\text { large-scale survey } \\
\text { aimed at practitioners } \\
\text { of largescale agile } \\
\text { development. }\end{array}$ & $\begin{array}{l}\text { The study } \\
\text { provided an } \\
\text { overview of the } \\
\text { development } \\
\text { process used by } \\
\text { a practitioner-led } \\
\text { collaborative } \\
\text { team to develop } \\
\text { a definition of } \\
\text { Agile culture, a } \\
\text { brief description } \\
\text { of the artefacts } \\
\text { produced, and } \\
\text { an analysis of } \\
\text { the team process } \\
\text { using the } \\
\text { Interdisciplinary } \\
\text { Collaboration } \\
\text { Model }\end{array}$ & $\begin{array}{l}\text { The effect of } \\
\text { individual's } \\
\text { culture norms } \\
\text { has on the } \\
\text { cultural } \\
\text { behaviour at } \\
\text { work that has } \\
\text { not been } \\
\text { considered as } \\
\text { the cultural } \\
\text { characteristics. } \\
\text { The individual's } \\
\text { cultural } \\
\text { characteristics } \\
\text { can be studied } \\
\text { to determine } \\
\text { how it affects } \\
\text { organisation in } \\
\text { adopting agile } \\
\text { methodologies. }\end{array}$ & $\begin{array}{l}\text { The finding from } \\
\text { this study } \\
\text { suggests that the } \\
\text { main } \\
\text { common } \\
\text { challenges for } \\
\text { successful agile } \\
\text { adoption between } \\
\text { the public and } \\
\text { private sectors are } \\
\text { organisation } \\
\text { culture, } \\
\text { communication, } \\
\text { feedback and } \\
\text { confidence. }\end{array}$ & $\begin{array}{l}\text { The findings } \\
\text { contribute to the } \\
\text { extant literature } \\
\text { by integrating the } \\
\text { competing values } \\
\text { model of culture } \\
\text { into the literature } \\
\text { on factors } \\
\text { affecting agile } \\
\text { development at } \\
\text { the IT department } \\
\text { level. }\end{array}$ & $\begin{array}{l}\text { The study } \\
\text { contributed to } \\
\text { a deeper } \\
\text { exploration of } \\
\text { the theme by } \\
\text { suggesting } \\
\text { significant } \\
\text { correlations } \\
\text { between the } \\
\text { adoption of } \\
\text { agile practices } \\
\text { and cultural } \\
\text { assumptions } \\
\text { of different } \\
\text { organisations }\end{array}$ & $\begin{array}{l}\text { The study } \\
\text { suggests that the } \\
\text { empowering } \\
\text { culture and } \\
\text { democratic } \\
\text { leadership from } \\
\text { Sweden encourage } \\
\text { the trust and } \\
\text { transparency } \\
\text { based behaviour } \\
\text { among the } \\
\text { offshore members }\end{array}$ & $\begin{array}{l}\text { Group culture, the } \\
\text { culture of } \\
\text { development and } \\
\text { rational culture } \\
\text { promote the } \\
\text { acceptance of the } \\
\text { agile } \\
\text { methodology, } \\
\text { while the } \\
\text { hierarchical } \\
\text { hinders } \\
\text { acceptance } \\
\text { culture. Further, } \\
\text { customer } \\
\text { satisfaction can be } \\
\text { considered as an } \\
\text { important factor in } \\
\text { the acceptance of } \\
\text { the treaty } \\
\text { methodology }\end{array}$ & $\begin{array}{l}\text { Study adds to the literature } \\
\text { on Agile Software } \\
\text { Development (ASD) } \\
\text { assimilation by providing } \\
\text { insights concerning a key } \\
\text { ASD assimilation gap. This } \\
\text { study provides a novel } \\
\text { understanding of ASD } \\
\text { assimilation beyond the } \\
\text { acceptance } \\
\text { stage }\end{array}$ \\
\hline \multicolumn{10}{|c|}{ Section C: Quality Assessment } \\
\hline Quality total score & 15 & 13 & 17 & 16 & 12 & 17 & 13 & 18 & 17 \\
\hline
\end{tabular}

